\title{
Kenevir Dokuma Kumaşa Enzimatik Ön İşlemlerin Etkisi
}

\author{
Effect of Enzymatic Pre-treatments on Hemp Woven Fabrics
}

\author{
Burcu YILMAZ ŞAHIINBAŞKAN \\ Marmara Üniversitesi, Teknoloji Fakültesi, Tekstil Mühendisliği Bölümü, 34722, İstanbul/Türkiye
}

$\ddot{O} \mathbf{z}$

Kenevir lifi tarih boyunca tekstil materyallerinde doğal elyaf olarak kullanılmış, zaman içinde önemini kaybetmiştir. Ancak son yıllarda, tekstilde biyobozunurluğun ve sürdürülebilirliğin önem kazanması ile alternatif doğal liflerin önemi de oldukça artmıştır. Kenevir bitkisinin kontrollü ekiminin serbest bırakılması ile bu lifin tekstilde kullanım olanakları yeniden araştırılmaya başlanmıştır. Bu çalışmada, kenevir dokuma kumaşın enzimlerle ön işlem olanakları araştırılmıştır. $\mathrm{NaOH}, \mathrm{H}_{2} \mathrm{O}_{2}$ ve $\alpha$-amilaz, pektinaz, lakkaz enzimleri uygulanarak üç farklı yönteme göre ön terbiye sonrası kumaş performans özellikleri karşılaştırılmıştır. Yöntem 1'de amilaz ile haşılı sökülen kumaş, NaOH ile hidrofilleştirilip ardından $\mathrm{H}_{2} \mathrm{O}_{2}$ ile ağartılmıştır. Yöntem 2'de haşılı sökülen kumaş, pektinazla hidrofilleştirilip ardından $\mathrm{H}_{2} \mathrm{O}_{2}$ ile ağartılmıştır. Yöntem 3'de kumaş, Yöntem 2'ye göre hidrofilleştirilip ardından lakkazla işleme tabi tutulmuştur. Kumaşların hidrofiliteleri, renk koordinatları, sarılık indeksleri, mukavemetleri, uzamaları ve buruşmazlık açıları değerlendirilmiştir. En iyi hidrofilite (1,46 s) Yöntem 2 sonrası elde edilmiştir. Enzimatik işlemler sonrası, renklendirme öncesi uygun kumaş zemin renginin elde edilebilmesi için optimizasyon gerekliliği ortaya çıkmıştır. İşlemler kumaşların kopma mukavemetinde ve uzamasında önemli bir değişim meydana getirmemiştir. Yöntem 1'e göre işlem gören kumaşların en yüksek buruşmazlık açısına $\left(78^{\circ}\right)$ sahip olduğu görülmüştür. Sonuç olarak kenevir elyafın yakın gelecekte öneminin tekrar artacağı ve endüstriyel tekstil uygulamalarında kullanım potansiyelinin olduğu söylenebilir.

Anahtar kelimeler: Kenevir, Dokuma kumaş, Enzim, Ön işlem, Sürdürülebilirlik.

\begin{abstract}
Hemp fibre was used as a natural fiber for textiles in ancient times and lost its importance over time. In recent years, due to the importance of biodegrability and sustainability, the importance of alternative natural fibers has also increased. The use of hemp as a textile fiber has been re-investigated with the release of controlled cultivation of cannabis plants. In this work, treatment possibilities of hemp woven fabrics with enzymes were investigated. Performance of treated fabrics by three different methods with $\mathrm{NaOH}, \mathrm{H}_{2} \mathrm{O}_{2}$ and $\alpha$-amylase, pectinase, laccase enzymes was compared. In Method 1, desized fabric with amylase was scoured with $\mathrm{NaOH}$ and than bleached with $\mathrm{H}_{2} \mathrm{O}_{2}$. In Method 2, desized fabric was scoured with pectinase and bleached with $\mathrm{H}_{2} \mathrm{O}_{2}$. In Method 3, scoured fabric by Method 2 was treated with laccase. Hydrophility, colour coordinates, yellowness index, tensile strength, elongation and wrinkle recovery of all woven were evaluated. The highest hydrophility $(1,46 \mathrm{~s})$ was obtained by Method 2. The optimization of the process was necessary for coloration in light colours. Treatments did not cause a significant change in strength and elongation of fabrics. The highest recovery angle $\left(78^{\circ}\right)$ was obtained by Method 1. Finally, hemp has potential to use for industrial applications.
\end{abstract}

Keywods: Hemp, Woven fabric, Enzyme, Pre-treatment, Sustanability

\section{GİRIŞ}

Kenevir, insanlık tarihi boyunca yetiştirilen ilk kültür bitkilerinden olup saplarından lif, tohumlarından ise yağ elde edilmektedir. Isırgangilere yakın, cannabinacea familyasına mensuptur. Cannabis sativa ve canabis indica olmak üzere iki türü bulunmaktadır. Cannabis sativa lif üretimi için kullanılırken, canabis indica narkotik özellikleri nedeni ile dünya çapında yasaklanmıştır [1-3].

Kenevirin ana vatanı Orta Asya olarak kabul edilmiştir. Tarihi kaynaklar incelendiğinde M.Ö. 2800 yıllarında Çin’de kenevir bitkisinin tarımının yapılmış olduğu ve lifinin kullanıldığı görülmektedir. Gerçekleştirilmiş arkeolojik kazılar sonrası 
ise M.Ö. 8000 yıllarında kenevirden üretilmiş kumaş kalıntılarına rastlanmıştır. Kenevirden elde edilen tekstiller 19. yy'ın sonlarına kadar önemini koruyarak ülkelerin ekonomilerini şekillendirmiş, ancak 20. yy'da gelişen teknolojiyle beraber pamuk lifinden daha ince ipliklerin elde edilmesi, daha hafif kumaşların üretimine geçilmesi ile önemini kaybetmeye başlamıştır. Yine aynı yüzyıl ilk çeyreğinde esrar karşıtı yasaların çıkarılması ile kenevir tarımı büyük sekteye uğramıştır. Sanayi devrimine paralel olarak sentetik liflerin üretiminin başlaması da kenevir tekstillerin eski değerinin yitirmesinin bir başka sebebi olmuştur [2-3].

Son y1llarda doğal, biyobozunur ve sürdürülebilir materyallerin oldukça önem kazanmaya başlamasıyla, kenevir lifi de, petrol türevi sentetik liflerle karşılaştırıldığında, yüksek ekolojik özellikleri ve organik üretim potansiyeli ile ön plana çıkmıştır [1-4]. Ekolojik bilincin artması ve sürdürülebilirliğin büyük önem kazanması ile dünyada ve ülkemizde kenevir lifi üretiminde önemli miktarda artış göze çarpmaktadır. Kenevir bitkisi yetiştirilmesi esnasında pamuk ve ketenden farklı olarak gübre ve tarım ilacına ihtiyaç duymadığından, sürdürülebilir ve çevre dostu olarak üretilebilmektedir [13]. Günümüz itibariyle ülkemizde Amasya, Antalya, Bartın, Burdur, Çorum, İzmir, Kastamonu, Kayseri, Karabük, Kütahya, Malatya, Ordu, Rize, Samsun, Sinop, Tokat, Uşak, Şanlıurfa, Yozgat ve Zonguldak olmak üzere 20 ilde izne ve denetime bağlı olarak endüstriyel kenevir yetiştiriciliği yapılabilmektedir. Çeşitli araştırmalar ve projeler kapsamında kenevirden üretilen tekstil ürünlerinin geliştirilmesi, katma değeri yüksek ürünler elde edilmesi ve üretimin sürdürülebilmesi konusunda çalışmalar devam etmektedir $[2,3]$.

Gömlek, pantolon, etek vb. iç/dış giyim ürünleri, havlu, perde, halı, döşemelik kumaş vb. ev tekstil ürünleri, şapka, çanta, cüzdan vb. aksesuarlar \%100 kenevir lifinden ve/veya kenevir lifi ile farklı oranlarda çeşitli liflerin karışımları ile üretilebilmektedir. Ayrıca kompozit malzeme üretiminde de kenevir lifi kullanılabilmekte olup, son yıllarda otomotiv sektöründe çeşitli kompozit malzemeler olarak ve inşaat sektöründe izolasyon malzemesi olarak kullanım alanı bulmaktadır [1-6].

Doğal bir selülozik lif olan kenevir, yapısından selülozun yanı sıra hemiselüloz, lignin ve pektin gibi safsızlıklar içermektedir. Lignin, selülozdan sonra ikinci en çok bulunan biyopolimerdir. $\mathrm{Bu}$ biyopolimer liflerin reaktivitesini artt1rırken, life sert bir tutum vermektedir. Kenevir elyafi, $20 \pm 2$ ${ }^{\circ} \mathrm{C}, \% 65$ bağıl nemde $\% 12$ nem almaktadır [2].

Kenevir lifleri yüksek mukavemet, yüksek nem çekme, nefes alabilirlik kabiliyeti, boncuklanma oluşturmama, anti bakteriyellik, UV koruma, anti alerjik ve iyi elektrostatik özellik göstermesi ile katma değeri yüksek ürünlerin üretiminde tercih edilmektedir $[2,3,6]$. Bu liflerin yüzey özellikleri alkali işlemler ile geliştirilebilmektedir. \% 6 Sodyum hidroksit ile $40{ }^{\circ} \mathrm{C}$ 'de 24 saat, $1 / 20$ oranında işlem gören kenevir lifi, kullanıldığı kompozit yapının mukavemetini yaklaşık \%20 oranında arttırmaktadır [7]. Tekstil elyafının yüzey özelliklerini geliştirmek amacı ile uygulanabilecek bir diğer alkali madde olan sodyum karbonatla gerçekleştirilen işlemlerle, kenevirin selüloz oranında herhangi bir kayıp olmadan yapısındaki safsızlıklar giderilerek, \%15-17 oranında ağırlık kayıpları ile yüzey modifikasyonu sağlanmıştır. Sonrasında sodyum karbonat ile işlem görmüş kenevir ile yüksek performansta kompozit malzemeler geliştirilmiştir [8]. Yine farklı kompozit malzemelerin geliştirilmesi için gerçekleştirilen bir diğer araştırmada kenevir elyafı lakkaz enzimi ile ön işleme tabi tutulmuştur. Enzimatik işlem sonrası termal ve mukavemet özelliklerinde önemli artışların meydana geldiği rapor edilmiştir [9].

Bu deneysel çalışmada, \%100 kenevir dokuma kumaşa boyama ve/veya baskı işlemleri öncesi uygulanabilecek haş1 sökme, hidrofilleştirme ve ağartma olmak üzere bir dizi ön terbiye işlemi uygulanmıştır. Ön terbiye işlemi sonrasında kumaşların hidrofiliteleri, renk koordinatları, sarılık indeksleri, kopma mukavemeti ve uzama (\%) test sonuçları ile buruşmazlık açısı tayini sonrası performansları değerlendirilmiştir.

\section{MATERYAL VE YÖNTEM}

\subsection{Materyal ve Kimyasal Maddeler}

Gerçekleştirilen deneysel çalışmalarda, Nm 4 kenevir ipliklerinden bezayağı dokunmuş \%100 kenevir ham kumaş kullanılmıştır. Uygulamalarda, ham kumaştan hazırlanan $5 \mathrm{~g}$ ağırlığında örnekler ile çalışılmıştır. Deneysel çalışmalarda kullanılan tüm kimyasal maddeler, maddelerin ticari isimleri ve üretici firmaları Tablo 1'de özetlenmiştir.

Islatıcı olarak kullanılan Uniwett HGA; hızlı 1slatma, y1kama, emülsifiye ve dispersiyon gücüne sahiptir. Alkaliye dayanıklı olması ve köpük yapmaması nedeniyle her türlü elyafın ön işlemlerinde kullanılabilmektedir.

Prestogen P; hidrojen peroksit ile tekstil materyalinin ağartılması sırasında, hidrojen peroksidin parçalanmasını azaltarak stabilize eden, organik bileşiklerden oluşmuş bir tekstil yardımcı kimyasalıdır.

Aquazym Ultra $1200 \mathrm{~L}$; haşıl sökme işlemi için kullanılan, düşük sıcaklıkta etkin $\alpha$-amilaz enzimidir. Bu enzim için optimum çalışma şartları, $\mathrm{pH}$ 6-7, 0,25-1,3 g/L enzim miktarı, 30-70 ${ }^{\circ} \mathrm{C}$ sicaklık aralığında, 20-60 dakika olarak önerilmektedir. Aquazym Ultra 1200 L kumaş üzerindeki nişasta haşılını elyafa zarar vermeden hidroliz ederek 
çözebilmekte ve dekstirine dönüştürmektedir. Güçlü etkisi ve yüksek stabilizetesi sayesinde çeşitli haşıl sökme makinaları ve işlemleri ile uyum göstermektedir.

Scourzym L; 50-60 ${ }^{\circ} \mathrm{C}$ sicaklık aralı̆̆ında kullanılan, pH 8-9 iken aktif olan bir pektinaz enzimidir. Novalite IIS; $\mathrm{pH}$ 4,5-5,5 aralığında, $45-55^{\circ} \mathrm{C}$ sıcaklıkta, 25-35 dakikada, \%1-2 konsantrasyonda kullanıldığında etkili sonuçlar sağlayan bir lakkaz enzimidir.

Tablo 1. Deneysel çalışmalarda kullanılan kimyasal maddeler

\begin{tabular}{|l|l|l|}
\hline $\begin{array}{l}\text { Kullanılan Kimya- } \\
\text { sal Madde }\end{array}$ & Ticari İsim & Üretici Firma \\
\hline $\begin{array}{l}\text { Sodyum hidroksit } \\
(\mathrm{NaOH})\end{array}$ & - & Merck \\
\hline $\begin{array}{l}\text { Hidrojen peroksit, } \\
\% 35\left(\mathrm{H}_{2} \mathrm{O}_{2}\right)\end{array}$ & - & Merck \\
\hline $\begin{array}{l}\text { Sodyum klorür } \\
(\mathrm{NaCl})\end{array}$ & - & Merck \\
\hline $\left.\begin{array}{l}\text { Kalsiyum klorür } \\
(\mathrm{CaCl}\end{array} \mathrm{H}_{2} \mathrm{O}\right)$ & - & Panreac Quimica Sa \\
\hline Asetik asit, \%100 & - & Merck \\
\hline Islatıc1 & Uniwet HGA & Alfa Kimya \\
\hline Organik stabilizatör & Prestogen P & BASF \\
\hline Sabunlama maddesi & Perlavin OSV & Dr.Petry \\
\hline Amilaz enzimi & Aquazym ultra 1200 L & Novozymes \\
\hline Pektinaz enzimi & Scourzym L & Novozymes \\
\hline Lakkaz enzimi & Novalite IIS & Novozymes \\
\hline
\end{tabular}

\section{2. Ön İşlemler}

$\% 100$ kenevir dokuma kumaş numunlerine, Yöntem 1, 2 ve 3 olmak üzere isimlendirilen üç farklı yönteme göre bir dizi ön işlem uygulanmıştır. Yöntem 1'de numuneler enzimatik olarak haşıl sökme işlemine uygulandıktan sonra sodyum hidroksitle hidrofilleştirilmiş, ardından hidrojen peroksit ile ağartılmıştır. Yöntem 2'de enzimatik olarak haşılı sökülen kumaş numuneleri pektinaz enzimi ile hidrofilleştirilmiş, Yöntem 1 ile aynı şartlarda hidrojen peroksit ile ağartılmıştır. Yöntem 3'de ise Yöntem 2'de uygulanan şekilde enzimatik olarak haşılı sökülen ve yine enzimatik olarak hidrofilleştirilen kumaş numuneleri lakkaz enzimi ile işleme tabi tutulmuştur. Tüm yöntemlerde uygulanan kimyasal maddelerin miktarları, uygulama sıcaklık ve zamanları, her bir işlem adımı sonrası uygulanan yıkama ve kurutma koşulları Tablo 2'de sunulmuştur.

\subsection{Kullanılan Teçhizat, Standartlar ve Test Metotları}

Tüm kumaş numunelerinin hidrofiliteleri AATCC-79-2007 standardına göre ölçülmüştür. K/S değerleri, CIELab renk koordinatları, ve sarılık indeksleri X-rite Ci6xBT taşınabilir spektrofotometresi ile $\mathrm{D}_{65}$ gün 1 şığı altında, $10^{\circ}$ standart gözlemci ile gerçekleştirilen ölçümler yardımı ile hesaplanmıştır. Uygulamalar sonucunda farklı yöntemlere göre ön işlem gören kumaş numunlerinin ipliklerine ait kopma mukavemeti ve \% uzama oranları 'Instron 4411' marka ve modelde iplik mukavemeti ölçme cihazı ile, TS 245 EN ISO 2062 standardına göre incelenmiştir. Ölçümler sırasında çene kuvveti $5 \mathrm{kgf}$, çeneler arası mesafe $250 \mathrm{~mm}$ ve çene hızı $250 \mathrm{~mm} /$ dak olarak alınmıştır. Her bir test, kumaşın atkı ve çözgü yönü aynı iplik olmasından dolayı, ham ve işlem görmüş kumaş numunlerinin çözgü yönünden sökülen iplikelere beş tekrarlı uygulanmıştır. Buruşmazlık açıları ise, AATCC 66-2003 (Dokuma Kumaşlarda Buruşmazlık Açısı Ölçümü) standardına göre James H.Heal marka Buruşmazlık Açısı Ölçüm Cihazı ile tayin edilmiştir.

Tablo 2. Uygulama yöntemleri

\begin{tabular}{|c|c|c|c|c|c|c|}
\hline Yöntemler & İşlemler & Uygulama Miktarları & $\begin{array}{c}\text { Sicaklık } \\
\left({ }^{\circ} \mathrm{C}\right)\end{array}$ & $\begin{array}{c}\text { Zaman } \\
\text { (dak) }\end{array}$ & Yıkama Koşulları $^{a}$ & Kurutma Koşulları \\
\hline \multirow{3}{*}{ Yöntem 1} & Haş1 Sökme & $\begin{array}{l}1 \mathrm{~g} / \mathrm{L} \text { 1slatic1 } \\
1 \mathrm{~g} / \mathrm{L} \alpha \text {-amilaz enzimi } \\
0,5 \mathrm{~g} / \mathrm{L} \mathrm{CaCl}{ }_{2} \cdot 2 \mathrm{H}_{2} \mathrm{O} \\
6 \mathrm{~g} / \mathrm{L} \mathrm{NaCl}\end{array}$ & 65 & 60 & Y1kama 1 & Oda koşulları \\
\hline & Hidrofilleştirme & $\begin{array}{l}0,2 \mathrm{~mL} / \mathrm{L} \text { 1slatic1 } \\
10 \mathrm{~g} / \mathrm{L} \mathrm{NaOH}\end{array}$ & 95 & 60 & Y1kama 2 & Oda koşulları \\
\hline & A ğartma & $\begin{array}{l}0,2 \mathrm{~mL} / \mathrm{L} \text { 1slatıc1 } \\
11,4 \mathrm{~mL} / \mathrm{L} \mathrm{H}_{2} \mathrm{O}_{2}(\% 35) \\
1 \mathrm{~g} / \mathrm{L} \mathrm{NaOH} \\
2 \mathrm{~g} / \mathrm{L} \text { Organik stabilizatör }\end{array}$ & 80 & 45 & Y1kama 3 & Oda koşulları \\
\hline
\end{tabular}




\begin{tabular}{|c|c|c|c|c|c|c|}
\hline \multirow[t]{3}{*}{ Yöntem 2} & Haş1l Sökme & $\begin{array}{l}1 \mathrm{~g} / \mathrm{L} \text { 1slatic1 } \\
1 \mathrm{~g} / \mathrm{L} \alpha \text {-amilaz enzimi } \\
0,5 \mathrm{~g} / \mathrm{L} \mathrm{CaCl}_{2} \cdot 2 \mathrm{H}_{2} \mathrm{O} \\
6 \mathrm{~g} / \mathrm{L} \mathrm{NaCl}\end{array}$ & 65 & 60 & Y1kama 1 & Oda koşulları \\
\hline & Hidrofilleştirme & $\begin{array}{l}0,2 \mathrm{~mL} / \mathrm{L} \text { slatic1 } \\
\% 1,8{\text { (e.a.ü. })^{\mathrm{b}} \text { pektinaz en- }} \\
\text { zimi }\end{array}$ & 55 & 30 & Y1kama 1 & Oda koşulları \\
\hline & Ağartma & $\begin{array}{l}0,2 \mathrm{~mL} / \mathrm{L} \text { 1slatic1 } \\
11,4 \mathrm{~mL} / \mathrm{L} \mathrm{H}_{2} \mathrm{O}_{2}(\% 35) \\
1 \mathrm{~g} / \mathrm{L} \mathrm{NaOH} \\
2 \mathrm{~g} / \mathrm{L} \text { Organik stabilizatör }\end{array}$ & 80 & 45 & Y1kama 3 & Oda koşulları \\
\hline \multirow[t]{3}{*}{ Yöntem 3} & Haş1l Sökme & $\begin{array}{l}1 \mathrm{~g} / \mathrm{L} \text { 1slatic1 } \\
1 \mathrm{~g} / \mathrm{L} \alpha \text {-amilaz enzimi } \\
0,5 \mathrm{~g} / \mathrm{L} \mathrm{CaCl} \cdot 2 \mathrm{H}_{2} \mathrm{O} \\
6 \mathrm{~g} / \mathrm{L} \mathrm{NaCl}\end{array}$ & 65 & 60 & Y1kama 1 & Oda koşulları \\
\hline & Hidrofilleştirme & $\begin{array}{l}0,2 \mathrm{~mL} / \mathrm{L} \text { 1slatic1 } \\
\% 1,8 \text { (e.a.ü.) pektinaz enzimi }\end{array}$ & 55 & 30 & Y1kama 1 & Oda koşulları \\
\hline & Ağartma & $\begin{array}{l}0,2 \mathrm{~mL} / \mathrm{L} \text { 1slatic1 } \\
\% 0,5 \text { (e.a.ü.) lakkaz enzimi }\end{array}$ & 55 & 40 & Y1kama 1 & Oda koşulları \\
\hline
\end{tabular}

${ }^{a}$ Yıkama 1: Uygulama yapılan kumaş numuneleri $80^{\circ} \mathrm{C}$ sıcaklıkta 10 dakika yıkama işlemine tabi tutulmuştur.

Y1kama 2: Uygulama yapılan kumaş numuneleri $80^{\circ} \mathrm{C}$ sıcaklıkta 10 dakika, ardından $50{ }^{\circ} \mathrm{C}$ sıcaklıkta 10 dakika ve son olarak soğuk suda

10 dakika olmak üzere üç adımlı yıkama işlemine tabi tutulmuştur.

Y1kama 3: Uygulama yapılan kumaş numuneleri $70^{\circ} \mathrm{C}$ sıcaklıkta iki kez 10'ar dakika yıkanmış, asetik asit ile nötralize edilmiş, $1 \mathrm{~g} / \mathrm{L}$

Perlavin OSV ile kaynar sabunlanmış, $70{ }^{\circ} \mathrm{C}$ sıcaklıkta ikişer kez daha10'ar dakika yıkanmış ve son olarak soğuk su ile taşar durulanmıştır.

\section{BULGULAR VE TARTIŞMA}

Her üç yönteme göre ön ilem gören kenevir kumaşların hidrofiliteleri, kopma mukavemetleri ve buruşmazlık açıları test edilmiş, renk ölçümleri gerçekleştirilmiş ve \% uzama değerleri hesaplanmıştır. Gerçekleştirilen testler, ölçümler ve hesaplamalar ham kumaştan başlamak üzere her bir işlem adımında uygulanmış ve kumaş numuneleri Tablo 3'de görüldüğü şekilde kodlanmıştır.

Tablo 3. Kumaş numunelerine ait kodlar

\begin{tabular}{|l|l|}
\hline Kumaş Numunesi & Kod \\
\hline Ham Kumaş & A \\
\hline Haşılı Sökülmüş Kumaş & B \\
\hline NaOH ile Hidrofilleştirilmiş Kumaş & C \\
\hline $\mathrm{NaOH}$ ile Hidrofilleştirme Sonrası $\mathrm{H}_{2} \mathrm{O}_{2}$ ile Ağartılmış Kumaş & D \\
\hline Pektinaz ile Hidrofilleştirilmiş Kumaş & E \\
\hline Pektinaz ile Hidrofilleştirilme Sonrası $\mathrm{H}_{2} \mathrm{O}_{2}$ ile Ağartılmış Kumaşa & $\mathrm{F}$ \\
\hline $\begin{array}{l}\text { Pektinaz ile Hidrofilleştirilme Sonrası Lakkaz Enzimiyle İşlem } \\
\text { Görmüş Kumaş }\end{array}$ & $\mathrm{G}$ \\
\hline
\end{tabular}

\subsection{Hidrofilite Test Sonuçları}

Ham ve işlem görmüş kenevir kumaş numunelerine uygulanan hidrofilite testi sonucu elde edilen değerler Şekil 1'de görülmektedir.

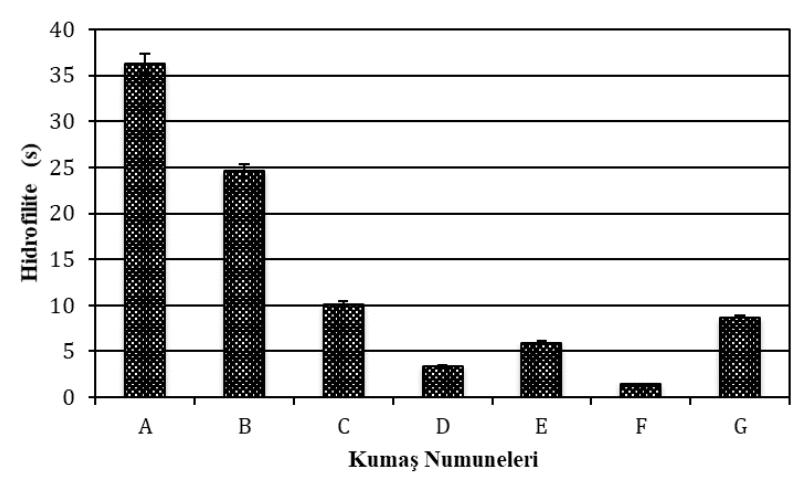

Şekil 1. Hidrofilite test sonuçları

Uygulanan tüm ön işlemler sonrasında numuneler ham kumaş ile karşılaştırıldığında hidrofilite artışı söz konusudur. Kenevir kumaş numunesini pektinaz enzimi ile hidrofilleştirmenin sodyum hidroksit ile hidrofilleştirmeden daha etkili olduğu Şekil 1'de açıkça görülmektedir. Hidrofilitesi en yüksek kenevir kumaşlar hidrofilleştirme işleminden sonra hidrojen peroksit ile ağartılandır. Lakkaz enzimi ile gerçekleştirilen uygulama sonrasında ise sodyum hidroksit ile hidrofilleştirmeden daha etkili fakat pektinaz enzimi ile hidrofilleştirilen ve hidrofilleştirme işlemleri sonrasında hidrojen peroksit ile ağartılan numunelerden daha düşük hidrofilite sonuçları elde edilmiştir. 


\subsection{Renk Ölçümü Sonuçları}

Kenevir kumaşlara ait spektrofotometrik ölçüm yolu ile elde edilen K/S, CIELab renk koordinatları ve sarılık indeksleri Şekil 2 ve Tablo 4'de sunulmuştur.

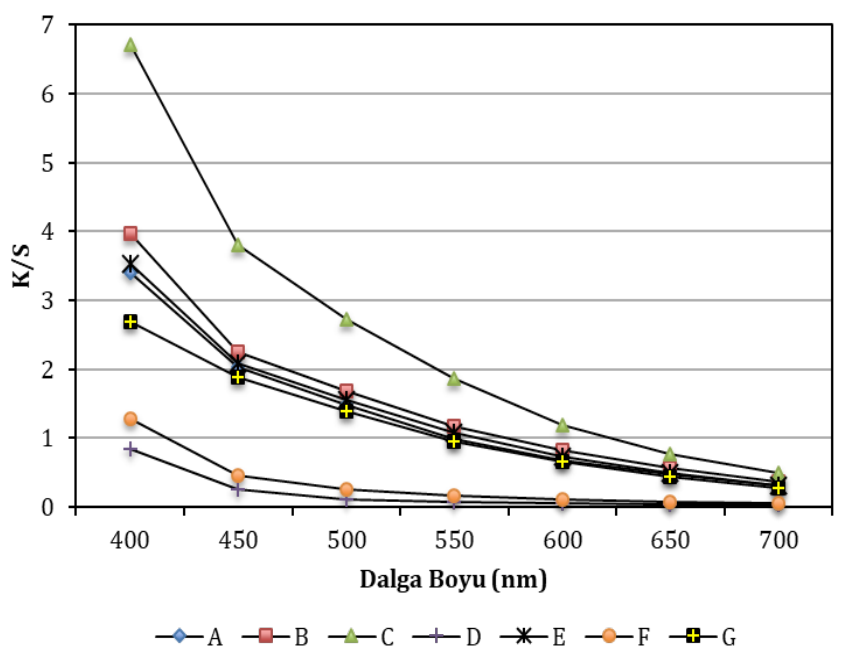

Şekil 2. Kenevir kumaş numunelerine ait K/S değerleri

Ham kenevir kumaşın rengi oldukça koyudur. Gerçekleştirilen enzimatik haş1 sökme işlemi kumaş numunelerinin renginde önemli bir değişime sebep olmamıştır. Sodyum hidroksit ile hidrofilleştirme işlemi ise kenevir kumaşın rengini daha da koyulaştırmıştır. Hidrojen peroksit ile ağartma sonrası kumaş zemin renklerinde olumlu yönde değişim meydana gelmiştir. Ancak bu ağartma işlemi sonrasında kumaş zemin renkleri beyaz değil açık sarı olarak elde edilmiştir. Lakkaz ile enzimatik işlem ise kumaş zemin renginde değişikliğe sebep olmamıştır. Diğer bir ifade ile Yöntem 3 sonrası kenevir kumaşın zemin rengi ham kenevir kumaş ile neredeyse aynidir.

Renk ölçümü sonucu elde edilen bulgular, \%100 kenevir dokuma kumaşa uygulanan her üç ön işlem yöntemi sonucunda ortaya çıkan zemin rengin açık tonlarda boyama/baskı ile renklendirmeye uygun olmadığını göstermektedir. Ancak koyu renklerde boyanacak/basılacak kenevir kumaşların ön işlemlerinde her üç yönteminde tercih edilerek uygulanabileceği görülmektedir.

\subsection{Kopma Mukavemeti Test Sonuçları}

Kenevir kumaşların çözgü yönündeki ipliklerinden sökülerek hazırlanan numunelerin kopma mukavemeti testi ve \% uzama sonuçları Tablo 5'de verilmektedir.
Tablo 4. Kumaş numunelerine ait CIELab renk koordinatları ve sarılık indeksleri (YI98)

\begin{tabular}{|c|c|c|c|c|c|c|}
\hline & & $a^{*}$ & $\mathbf{b}^{*}$ & $C^{*}$ & $\mathbf{h}^{\circ}$ & $\begin{array}{l}\text { Sarılık } \\
\text { Indeksi } \\
\text { (YI98) }\end{array}$ \\
\hline A & & 6,97 & 18,49 & 19,76 & 69,35 & 53,73 \\
\hline B & & 6,84 & 17,49 & 18,78 & 68,64 & 52,90 \\
\hline C & & 9,47 & 19,79 & 21,94 & 64,43 & 66,22 \\
\hline D & & $-1,11$ & 17,95 & 17,98 & 93,54 & 33,10 \\
\hline $\mathbf{E}$ & & 7,46 & 17,62 & 19,13 & 67,05 & 53,17 \\
\hline F & & 1,66 & 18,41 & 18,48 & 84,85 & 38,24 \\
\hline G & & 7,12 & 17,77 & 19,14 & 68,17 & 52,08 \\
\hline
\end{tabular}

Tablo 5. Kumaş numunelerine ait kopma mukavemeti ve uzama (\%) test sonuçları

\begin{tabular}{|l|l|l|}
\hline Kumaşlar Numuneleri & Kopma Mukavemeti (cN/tex) & $\begin{array}{l}\text { Uzama } \\
\mathbf{( \% )}\end{array}$ \\
\hline A & 9,13 & 4,23 \\
\hline B & 7,61 & 4,56 \\
\hline C & 9,81 & 6,01 \\
\hline D & 4,23 & 4,97 \\
\hline E & 8,03 & 4,17 \\
\hline F & 7,76 & 4,00 \\
\hline G & 7,66 & 4,53 \\
\hline
\end{tabular}

Yöntem 2'ye ön işlem gören numunelerin en düşük kopma mukavemetine $(4,23)$ sahip olduğu görülmektedir. $\mathrm{Bu}$ yöntemde enzimatik haşıl sökme sonrası sodyum hidroksit ile işlem gören kumaşlar ardından hidrojen peroksit ile ağartıldığında kopma mukavemeti sonucunda bu düşme beklenen bir sonuçtur. Yöntem 3'e göre enzimatik işlem gören kumaş numunelerinin ipliklerine ait kopma mukavemeti (7,66 cN/tex) ve \% uzama (\% 4,53) değerlerinde önemli bir değişim meydana gelmemiştir. Enzimatik işlemlerin daha ılıman şartlarda uygulanıyor olması nedeni ile beklenen lif hasarının az olması elde edilen bu sonuç ile örtüşmektedir. 


\subsection{Buruşmazlık Testi Sonuçları}

Ham ve ön işlem görmüş kenevir kumaşlar \%65 bağıl nem ve $20 \pm 5^{\circ} \mathrm{C}$ sıcaklıkta bir gün dinlenmeye birakılmış, buruşmazlık açıları ölçülmüştür. Kuru buruşmazlık açısı ölçümleri hem atkı hem de çözgü yönünde gerçekleştirilmiş ve ortalamaları alınmıştır. Kumaşların atkı ve çözgü yönünde buruşmazlık açıları benzer bulunduğundan her bir kumaş için tek sonuç verilerek tüm sonuçlar Şekil 3'de sunulmuştur.

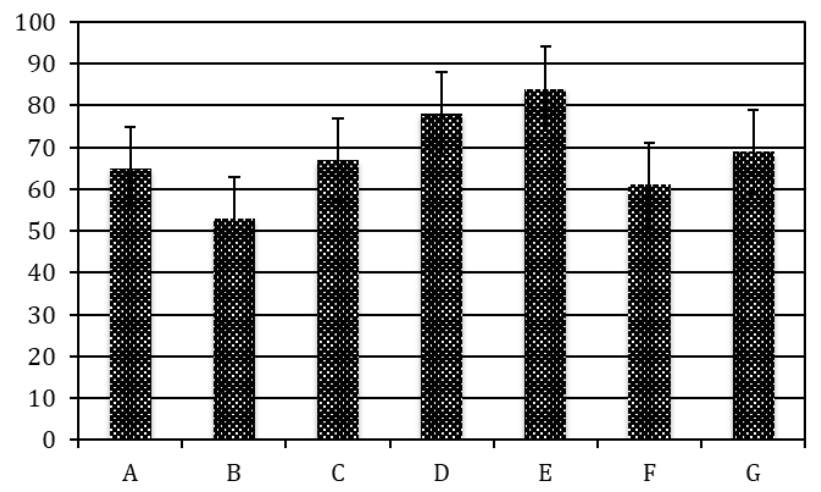

Şekil 3. Buruşmazlık açısı test sonuçları

Enzimatik haşıl sökme işlemi sonrası buruşmazlık açısı bir miktar düşmüş ancak bu işlem sonrası uygulanan hidrofilleştirme ve ağartma $\left(78^{\circ}\right)$ ile ham kumaştan $\left(65^{\circ}\right)$ daha yüksek değerlere ulaşmıştır. En yüksek buruşmazlık açısı haş1lı söküldükten sonra pektinaz enzimi ile hidrofilleştirilen numunelerde elde edilmiştir. Kenevir kumaşın en yüksek buruşmazlık açısına sahip olduğu ön işlem Yöntem 1 $\left(78^{\circ}\right)^{\prime}$ dir. Genel olarak her üç yöntem sonrası elde edilen numunelerin buruşmazlık açıları hem ham kumaştan hem de enzimatik haşı sökme $\left(53^{\circ}\right)$ sonrası elde edilen sonuçlardan yüksektir.

\section{GENEL DEĞERLENDİRME}

Biyobozunur ve sürdürülebilir bir lif olan kenevirden elde edilen tekstil materyallerinin renklendirme öncesi enzimatik ön işlem görmesi hidrofilite ve buruşmazlık özelliklerini geliştirmekte, mukavemet kaybını en aza indirmektedir. Ön işlemlerde gerçekleştirilecek optimizasyonlarla sarılık indeksinin düşürülüp uygun zemin renkte boyama ve/veya bask1 yolu ile renklendirilecek kenevir tekstil materyallerinin elde edilmesi mümkün gözükmektedir. Gelecek çalışmalarda, kenevir lifinin farklı oranlarda başka tekstil lifleri ile karıştırılması sonucu ön işlemlerin etkisinin geliştirebileceği düşünülmektedir. En eski doğal liflerden biri olan kenevirin, diğer doğal lifler gibi, önümüzdeki yakın gelecekte öneminin artacağ1 ve alternatif olarak endüstriyel uygulamalarda kullanım potansiyelinin var olduğu açıktır.

\section{KAYNAKLAR}

[1] Vantreese, V.L. (2002). Hemp Support: Evolution in EU Regulation. Journal of International Hemp Association, 7(12), $1-23$.

[2] Gedik, G., Avinç, O.O., Yavaş, A. (2010). Kenevir Lifinin Özellikleri ve Tekstil Endüstrisinde Kullanımıyla Sağladığ Avantajlar. Tekstil Teknolojisi ve Elektronik Dergisi, 4(3), 39-48. http://tekstil.tekstil.com/kenevir-2/ Erişim Tarihi: 04.06.2018.

[4] Gedik, G. (2010). Kenevir Liflerinden Üretilen Kumaşların Optimum Ağartma Koşullarının ve Yöntemlerinin Belirlenmesi, Yüksek Lisans Tezi, Pamukkale Üniversitesi Fen Bilimleri Enstitüsü.

[5] Mwaikambo, L.Y. \& Ansell, M.P. (2002). Chemical Modification of Hemp, Sisal, Jute and Kapok Fibers by Alkalization. Journal of Polymer Science, 84, 2222-2234.

[6] Ebskamp, M.J.M. (2002). Engineering Flax and Hemp For An Alternative to Cotton. Trends in Biotechnology, 20(6), 229-230.

[7] Hu, R. \& Lim J.K. (2007). Fabrication And Mechanical Properties of Completely Biodegradable Hemp Fiber Reinforced Polylactic Acid Composites. Journal of Composite Materials, 41(13), 1655-1669.

[8] Thomsen, A.B., Thygesen, A., Bohn, B., Nielsen, K.V., Pallesen, B. \& Jorgensen, M.S. (2006). Effects of Chemical-Physical Pre-treatment Processes on Hemp Fibres For Reinforcement of Composites and For Textiles. Industrial Crops and Products, 24 (2), 113-118.

[9] Ming, L. (2016). Pretreatment of Hemp Fibers For Utilization in Strong Biocomposite Materials. Ph.D Thesis, Technical University of Denmark, Centre of Bioproses and Engineering, Department of Chemical and Biochemical Engineering (Supervised by Prof. A.S. Meyer). 